Portland State University

PDXScholar

\title{
Uneven Development of the Sustainable City: Shifting Capital in Portland, Oregon
}

\author{
Erin Goodling \\ Portland State University, erin.goodling@pdx.edu \\ Jamaal Green \\ Portland State University, jamgreen@pdx.edu \\ Nathan McClintock \\ Portland State University, n.mcclintock@pdx.edu
}

Follow this and additional works at: https://pdxscholar.library.pdx.edu/usp_fac

Part of the Urban Studies Commons, and the Urban Studies and Planning Commons Let us know how access to this document benefits you.

\section{Citation Details}

Goodling, Erin; Green, Jamaal; and McClintock, Nathan, "Uneven Development of the Sustainable City: Shifting Capital in Portland, Oregon" (2015). Urban Studies and Planning Faculty Publications and Presentations. 107.

https://pdxscholar.library.pdx.edu/usp_fac/107

This Post-Print is brought to you for free and open access. It has been accepted for inclusion in Urban Studies and Planning Faculty Publications and Presentations by an authorized administrator of PDXScholar. Please contact us if we can make this document more accessible: pdxscholar@pdx.edu. 


\title{
Uneven Development of the Sustainable City: Shifting Capital in Portland, Oregon
}

\author{
Erin Goodling; Jamaal Green; Nathan McClintock* \\ Nohad A. Toulan School of Urban Studies and Planning \\ Portland State University \\ Portland, Oregon, U.S.A. \\ * - corresponding author \\ erin.goodling@pdx.edu \\ jamgreen@pdx.edu \\ n.mcclintock@pdx.edu
}

This is a post-print version of the following article: Goodling, Erin, Jamaal Green, \& Nathan McClintock (2015) Uneven Development of the Sustainable City: Shifting Capital in Portland, Oregon. Urban Geography doi:10.1080/02723638.2015.1010791.

\begin{abstract}
Portland, Oregon is renowned as a paradigmatic "sustainable city". Yet, despite popular conceptions of the city as a progressive ecotopia and the accolades of planners seeking to emulate its innovations, Portland's sustainability successes are inequitably distributed. Drawing on census data, popular media, newspaper archives, city planning documents, and secondary-source histories, we attempt to elucidate the structural origins of Portland's "uneven development", exploring how and why the urban core of this paragon of sustainability has become more White and affluent while its outer eastside has become more diverse and poor. We explain how a "sustainability fix" - in this case, green investment in the city's core - ultimately contributed to the demarcation of racialized poverty along $82^{\text {nd }}$ Avenue, a major north-south arterial marking the boundary of East Portland. Our account of structural processes taking place at multiple scales contributes to a growing body of literature on eco-gentrification and displacement and inner-ring suburban change while empirically demonstrating how Portland's advances in sustainability have come at the cost of East Portland's devaluation. Our "30,000 foot" perspective reveals systemic patterns that might then guide more fine-grained analyses of particular political-socio-cultural processes, while providing cautionary insights into current efforts to extend the city's sustainability initiatives using the same green development model.
\end{abstract}

Key Words: Built environment; gentrification; suburbanization of poverty; sustainability fix; uneven development; urban sustainability 
Self-congratulation occurs in the region each time our city reaches the "top 10" lists of good places to live in the USA. [But] we are deluding ourselves to think that this is universally an excellent place to live.

- Curry-Stevens, Cross-Hemmer, and Coalition of Communities of Color (2010, p. 122)

It's hard to find where I dwell because home is only a shell and the people I was raised with can't afford the raised rent so the neighborhood shifted and faded out of existence

- Portland rapper Luck-One (2011)

\section{Introduction}

Portland, Oregon's boosters highlight miles of bike lanes and light rail, an urban growth boundary that prevents sprawl and protects farmland, walkable 20-minute neighborhoods, yearround farmers markets, and an increasingly complex network of green infrastructure. Scholars and the popular press alike portray Portland as a leader in sustainability and livability (Berke and Conroy, 2000; Dyckhoff, 2012; Portney, 2005; SustainLane, 2008). Echoing the "win-win-win" discourse that typifies mainstream definitions of sustainability, municipal greening efforts lie at the center of the city's economic development strategy. A 2008 proclamation by Tom Potter, Mayor of Portland from 2005 to 2009, invokes such a promise:

Portland's support of local farmers and farmers markets, its explosion of green buildings and commitment to renewable energy, and its emphasis on mass transportation, including light rail and bicycles, shows that a city can not only be kind to the earth, but also flourish economically and grow by being green (SustainLane, 2008).

In step with a global trend (While, Jonas, and Gibbs, 2004), Portland's sustainability prowess has translated to a viable development approach, and policymakers and planners from around the world look to emulate the Portland model (Slavin and Snyder, 2011).

Yet, despite the accolades and economic growth, Portland's sustainability initiatives are far from panaceas for social inequities: many of Portland's roughly 600,000 residents lack regular access to hallmarks of the sustainable city, such as fresh and healthy food, safe neighborhoods, convenient transit, and affordable housing (Coalition for a Livable Future (CLF), 2013; GriffinValade, Kahn, and Adams-Wannberg, 2010). Some have argued that in the absence of explicit measures to confront disparities, sustainability initiatives can actually reproduce racialized and spatialized social inequalities (Gunder, 2006; Hope-Alkon and Agyeman, 2011; Jonas and While, 2007), highlighting, for example, how green development can drive gentrification and displacement (Bunce, 2009; Checker, 2011). Portland is no exception, particularly when it comes to gentrification and displacement.

Scholars and journalists have begun to scrutinize the intersection of land use planning and policy decisions, institutional racism, poverty, gentrification, and displacement in Portland (Bates, 2013; Curry-Stevens et al., 2010; Schmidt, 2012). With some exceptions (e.g., Gibson, 2007), however, few have situated Portland's changes within a longer historical geography that 
explains the structural factors driving public and private (dis)investment - and associated gentrification and displacement. In this paper, we therefore attempt to elucidate the structural origins of Portland's "uneven development" (Smith, 2008), exploring how and why the urban core of this paragon of sustainability has become more White and affluent, while its outer eastside has become more diverse and poor. We explain how a "sustainability fix" (White et al., 2004) in this case, green investment in the city's core - ultimately contributed to the demarcation of racialized poverty along $82^{\text {nd }}$ Avenue, a major north-south arterial marking the boundary of East Portland. Drawing attention to this "demarcated devaluation" (McClintock, 2011), our account of multi-scalar structural processes contributes to a growing body of literature on eco-gentrification and displacement (Checker, 2011; Dale and Newman, 2009; Dooling, 2009) and inner-ring suburban change (Hackworth, 2007; Niedt, 2006; Schafran, 2013), while empirically demonstrating how Portland's advances in sustainability have come at the cost of East Portland's devaluation. We recognize that overt discrimination, local politics, and class-based consumer demand play fundamental roles in the continued displacement of low-income residents and people of color, especially African Americans. But broad structural forces profoundly influence the contours of such politics across space and time. For this reason, we take a "30,000 foot" perspective to reveal systemic patterns that might then guide more fine-grained analyses of particular political-socio-cultural processes.

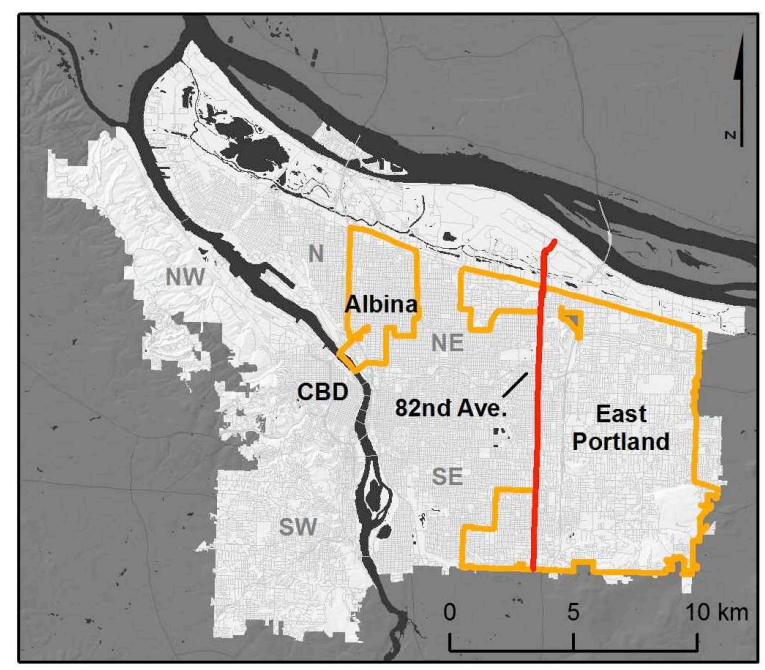

Figure 1. Portland, Oregon: the central business district (CBD) is just west of the Willamette River; Albina is across the river to the east and north; East Portland makes up the eastern-most section of the city; $82^{\text {nd }}$ Avenue is also marked. East Portland accounts for about one fourth of the city's landmass, and is home to roughly a quarter of Portlanders.

We begin the paper with a description of Portland's unevenness, followed by a review of relevant theories of capital-switching, uneven development, and gentrification-displacement. We then draw on census data, popular media, newspaper archives, city planning documents, and secondary-source histories to paint a broad-brush historical geography of Portland's transformation from World War II to the present. We highlight the role of suburbanization, specific city planning decisions, local-level politics, and interrelated demographic shifts in two areas of the city: East Portland and the inner-core Albina area (see Figure 1). While these two 
areas are not the only neighborhoods in Portland shaped by these dialectical processes, they provide what is perhaps the most dramatic and egregious illustration of uneven development, and how it frequently unfolds in a racialized manner. We conclude by addressing implications of this history for current efforts to extend the city's sustainability initiatives to East Portland. We hope that revealing how cycles of investment and disinvestment unevenly shape access to resources in a city celebrated for its sustainability planning can serve as a cautionary tale for those seeking to emulate Portland's green urbanist approach.

\section{Uneven Portland}

A handful of statistics begin to reveal Portland's disparities. Over 17\% of Portland residents and $22 \%$ of children live below the poverty line (ACS, 2008-2012), but this poverty is also racialized (see Table 1); for example, more than a third of the city's African American population lives below the poverty line, and median household income for African Americans and Latinos ranges from half to a third of that of White households. As in cities around the United States, Portland's socioeconomic disparities not only fall along racial lines, but also are spatial in nature. Over the last two decades, $82^{\text {nd }}$ Avenue has become a symbolic and material demarcation between a world-renowned sustainability mecca and its devalued hinterland. ${ }^{1}$

To the west, the city has become more affluent and White; to the east, it has become more diverse and poor. Four of the five census tracts in Portland experiencing the most dramatic drop in income (of $15 \%$ or more) between 2000 and 2010 are located east of $82^{\text {nd }}$ Avenue, and poverty rates for all races are higher in East Portland than in the rest of the city. Whereas numbers of people of color living in other areas of the city have dwindled, a full $45 \%$ of East Portlanders now identify as a person of color (compared with about $23 \%$ for Portland as a whole; see Figure 2) (ACS, 2008-2012; LTDB, 2013). ${ }^{2}$ These relatively recent demographic shifts make East Portland one of the most diverse areas in the state of Oregon, while underscoring the racial and spatial articulation of the city's poverty.

\footnotetext{
${ }^{1}$ We focus on East Portland at the city-scale given drastic changes to the area over the last decade or so. We identify our study area to include all of the area east of $82^{\text {nd }}$ Avenue, in addition to three neighborhoods (i.e., Cully, Mt. Scott-Arleta, and Brentwood-Darlington) just west of this dividing line, given their similar histories of development and annexation to neighborhoods east of $82^{\text {nd }}$. It is important to note, however, that East Portland is not homogenous; a finer-grained lens reveals considerable heterogeneity in East Portland, in terms of both urban form and socioeconomic characteristics, where some families, blocks, neighborhoods, and census tracts experience much greater poverty than others. Conversely, pockets of destitution remain in inner Portland. It is not our intent to obfuscate such diversity of experience or understate hardship experienced elsewhere in the city.

${ }^{2}$ Original longitudinal census data (LTDB, 2013) combines both population and area-weighted calculations to construct estimates of a census data set using 2010 census tract geographies. This dataset, which includes census years 1970, 1980, 1990, 2000 and 2010, adjusts count and mean variables for tracts whose geographies have changed (Logan, Xu, and Stults, 2012).
} 
POST-PRINT VERSION - Goodling, Green, \& McClintock - Urban Geography (2015)

Table 1. Population, income, and poverty by race/ethnicity in East Portland

\begin{tabular}{|c|c|c|c|c|c|c|}
\hline \multirow[t]{3}{*}{ Race/ethnicity } & \multirow{2}{*}{\multicolumn{2}{|c|}{$\begin{array}{c}\text { Population } \\
\qquad \begin{array}{c}\text { N } \\
(\%)\end{array}\end{array}$}} & \multirow{2}{*}{\multicolumn{2}{|c|}{$\begin{array}{c}\text { Average household } \\
\text { income } \\
\$\end{array}$}} & \multirow{2}{*}{\multicolumn{2}{|c|}{ Living in poverty }} \\
\hline & & & & & & \\
\hline & $\begin{array}{c}\text { East } \\
\text { Portland }\end{array}$ & $\begin{array}{l}\text { Rest of } \\
\text { Portland }\end{array}$ & $\begin{array}{c}\text { East } \\
\text { Portland }\end{array}$ & $\begin{array}{l}\text { Rest of } \\
\text { Portland }\end{array}$ & $\begin{array}{c}\text { East } \\
\text { Portland }\end{array}$ & $\begin{array}{l}\text { Rest of } \\
\text { Portland }\end{array}$ \\
\hline $\begin{array}{l}\text { Black or African } \\
\text { American alone }\end{array}$ & $\begin{array}{r}14,448 \\
(8 \%)\end{array}$ & $\begin{array}{c}23,453 \\
(5 \%)\end{array}$ & 37,911 & 36,394 & 38 & 33 \\
\hline $\begin{array}{l}\text { White alone, not } \\
\text { Hispanic or Latino }\end{array}$ & $\begin{array}{r}127,792 \\
(68 \%)\end{array}$ & $\begin{array}{r}329,644 \\
(77 \%)\end{array}$ & 57,225 & 82,521 & 20 & 12 \\
\hline Hispanic or Latino & $\begin{array}{r}28,374 \\
(15 \%)\end{array}$ & $\begin{array}{r}31,141 \\
(7 \%)\end{array}$ & 40,980 & 55,562 & 36 & 23 \\
\hline $\begin{array}{l}\text { American Indian and } \\
\text { Alaska Native alone }\end{array}$ & $\begin{array}{r}1,720 \\
(1 \%)\end{array}$ & $\begin{array}{r}2,673 \\
(<1 \%)\end{array}$ & 5,889 & 6,615 & 92 & 30 \\
\hline Asian alone & $\begin{array}{r}21,106 \\
(11 \%)\end{array}$ & $\begin{array}{r}21,643 \\
(5 \%)\end{array}$ & 60,450 & 80,747 & 18 & 14 \\
\hline $\begin{array}{l}\text { Native Hawaiian and } \\
\text { other Pacific Islander } \\
\text { alone }\end{array}$ & $\begin{array}{r}1,435 \\
(1 \%)\end{array}$ & $\begin{array}{r}2,101 \\
(<1 \%)\end{array}$ & N/A & 7,759 & 44 & 26 \\
\hline Some other race alone & $\begin{array}{r}10,772 \\
(6 \%)\end{array}$ & $\begin{array}{r}986 \\
(<1 \%)\end{array}$ & 37,835 & 28,893 & 38 & 30 \\
\hline Two or more races & $\begin{array}{r}7,025 \\
(4 \%)\end{array}$ & $\begin{array}{r}16,234 \\
(4 \%)\end{array}$ & 40,738 & 43,418 & 26 & 19 \\
\hline Total & 188,949 & 427,875 & 40,146 & 42,739 & 21 & 13 \\
\hline
\end{tabular}

Source: American Community Survey (ACS), 2008-2012 5-year estimates. NB: Percentages sum to more than $100 \%$ given that respondents can select more than one race and that Hispanic/Latino are reported separately.

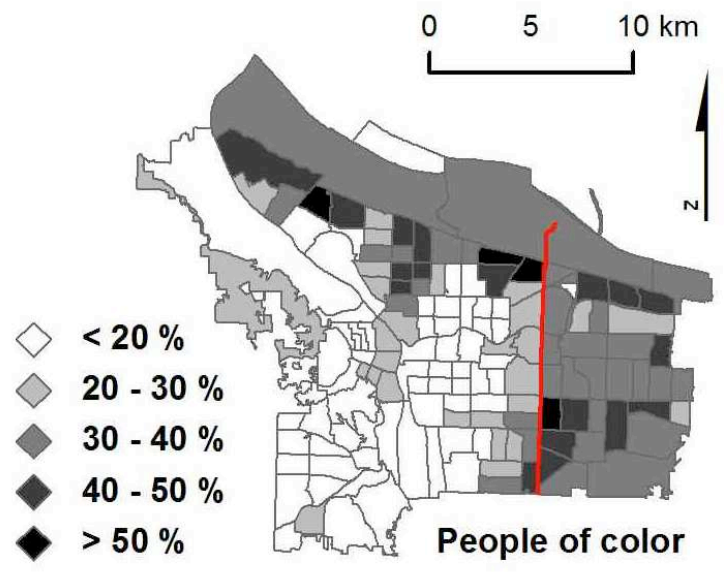

Figure 2. East Portland neighborhoods, as well as those to the north of the central city, are home to far more people of color than Portland's inner-core neighborhoods. Data source: LTDB, 2013. 
East Portland's neighborhoods differ markedly from those praised for their walkability west of $82^{\text {nd }}$ Avenue. The compact residential lots and quaint commercial districts that emerged along streetcar routes in the early part of the twentieth century - markers of "livability" that have earned Portland its laurels - are the norm in Portland's inner neighborhoods, but are markedly absent in the suburban neighborhoods east of $82^{\text {nd }}$ Avenue. If not for the iconic Pacific Northwest backdrop of evergreen Douglas fir trees, East Portland's used car dealerships, deteriorating tract housing and apartment complexes, and strip malls housing check-cashing stores and store-front churches could be mistaken for those of any declining inner-ring suburb in the United States. By any measure, East Portland residents are less likely to influence or benefit from municipal sustainability initiatives that make Portland stand out (CLF, 2013; Curry-Stevens et al., 2010; Griffin-Valade et al., 2010).

This particular geographic configuration of racialized poverty - this "other Portland" (Pein, 2011) east of $82^{\text {nd }}$ - is relatively new. Historically, as the home of Portland's segregated African American community, Albina was the center of racialized poverty in the metropolitan region. Gibson (2007) explains how, for over forty years, African Americans were segregated to Albina as a result of federally backed redlining and the exploitative practices of speculators, slumlords, bankers, and real estate agents. Over the last few decades, however, urban renewal funds have resulted in rising property values and an incoming wave of wealthier, mainly White residents to the area. Whereas incomes have dropped in recent years in East Portland, all six of Portland's census tracts with the greatest increase in income (of at least 60\%) from 2000 to 2010 are located west of $82^{\text {nd }}$ Avenue; two of these are located in Albina (LTDB, 2013). The influx of affluent newcomers has displaced many lower-income households, especially (but not only) African Americans (Bates, 2013; Gibson, 2007). Between 1990 and 2010, Albina lost more than 6,000 Black residents (LTDB, 2013); many have joined lower-income Whites and recent immigrants in East Portland, where housing is cheaper but basic services and amenities are lacking relative to other areas of the city.

\section{Theorizing uneven development and the sustainability fix}

Understanding the racialization and spatial concentration of Portland's poverty demands that we examine broad structural processes that undergird changes to the urban form at multiple spatial and temporal scales. For many critical urbanists, the particular urban form and demographic makeup of particular parts of the city are far from historical happenstance; rather, both are shaped by cycles of capital accumulation and devaluation and by the social processes (including policy-making and planning) that mediate them (Harvey, 1989; 2007; Logan and Molotch, 2007).

Since World War II, the United States has experienced a handful of key "capitalswitching" moments, periods when investment into new economic sectors and geographical spaces averts or "fixes" financial crises of overaccumulation and devaluation (Hackworth, 2007; Harvey, 1989). Capital accumulation occurs in multiple circuits of production. In the primary circuit, surplus value is captured through the production and consumption of goods and services. The secondary circuit is defined by investment in the built environment, "fixed capital" that facilitates production (and ultimately economic agglomeration) and social reproduction (e.g., housing). Finally, the tertiary circuit involves investment in sectors such as research and development, technology, education, and social services. Overaccumulation of capital or labor (or 
the possibility thereof) pushes state and private interests to invest in new areas, thus triggering a switching of capital flows between circuits and spaces.

The built environment is central to this process (Hackworth and Smith, 2001; Harvey, 1989). For example, investors can sink surplus capital accumulated in the primary circuit into new residential development where land prices are relatively cheap. Whether a peri-urban greenfield site or a vacant lot in a dilapidated neighborhood, there is always some physical location that is underdeveloped and/or devalued relative to others. It is here, when the gap between actual and potential market value is wide enough, that "redevelopment and rehabilitation into new land uses becomes a profitable prospect, and capital begins to flow back" (Smith, 1982, p. 149). New investment, in turn, generates fresh opportunities for accumulation through rent and real estate speculation. The aversion of crisis is only ever temporary, however. As fixed capital loses value - and its ability to produce profit - over time, capital must locate new spaces of development. Smith (1982) explains:

The development of one area creates barriers to further development, thus leading to underdevelopment, and ... the underdevelopment of that area creates opportunities for a new phase of development ... Capital jumps from one place to another, then back again, both creating and destroying its own opportunities for development (p. 151).

The cycle repeats in an ever-expanding and unevenly developed landscape (Hackworth, 2007; Harvey, 1989, 2007; Smith, 2008).

The first national-scale capital-switching period relevant to our study involves the familiar story of suburbanization - and concomitant devaluation of the inner city - in the decades following the Second World War. Prior to World War II, the Keynesian welfare state guided capitalist urbanization and reflected a central tension: the city was site of both production of surplus value (profit), as well as center of consumption and investment of that surplus value. But with the wartime manufacturing boom on the wane and veterans returning in search of work, the United States faced the prospect of rising unemployment. Moreover, the dense urban fabric in post-war U.S. cities offered little room for expansion of production or housing for returning veterans and their families. An alliance of actors from government, corporate, financial, and real estate sectors thus engineered a "spatial fix" in metropolitan areas all over the United States: a state-led expansion of physical infrastructure in the urban periphery that fostered the growth of the housing sector while facilitating the outward march of mostly White, middle-class families. In particular, federally subsidized highways and home loans (available, for the most part, only to Whites) helped finance this suburbanization project. The expansion was neither inevitable nor uncontested. Central-city interest groups engaged in their own competing "growth machine" projects in an effort to counter decentralization trends by encouraging the construction of new arterial highways into downtowns that would funnel suburbanites back to now disinvested urban cores (Beauregard, 2006; Harvey, 1989; Logan and Molotch, 2007; Walker, 1981).

Though suburban expansion (and investment in social sectors such as education and health care) "solved" the impending post-war national crisis, sprawling growth was far from a permanent fix. Even as the Keynesian approach allowed municipalities to stave off imminent crises of overaccumulation for a few decades, suburbanization ultimately cost dearly. The drastic retreat of tax-paying households and industrial production, particularly manufacturing, from city centers left municipal governments saddled with debt and starved by a shrinking tax base. Private, 
corporate, and national debt likewise ballooned, and the usual channels for surplus absorption of capital became saturated. Abandoned industrial cores and neighboring working-class housing stocks began to deteriorate. Inflation and the devaluation of money loomed large, and inner-city unemployment and poverty forced municipalities and the federal government to consider alternative strategies (ibid.).

Ultimately, this period of debt-fueled growth and inner-core disinvestment culminated in a worldwide property and financial market collapse in 1973. As investment in the built environment (the secondary circuit) slowed to a trickle, the crisis set the stage for the second major capital-switching moment relevant to our study. With stagflation devaluing the credit-based "fictitious" capital markets that had fueled suburban expansion, a new fix became necessary. The collapse served as justification for a conservative, anti-Keynesian approach that demanded privatization, devolution of power to local authorities, deregulation of markets, and lifting of tariffs and trade embargoes (Brenner and Theodore, 2002; Hackworth, 2007; Peck and Tickell, 2002). This "neoliberal turn" exacerbated capital's tendency toward uneven development. As before, this fix also took a spatial form; devalued inner city areas would once again serve as sites of accumulation, but this time through real estate and amenity-based development, rather than industry (Hackworth, 2007).

Starting in the 1980s, capital sought a safe-haven from an ongoing global recession, and cities have since seen a return of large-scale investment to their cores, with private profits frequently "lubricated" by public subsidies (Smith, 2002). In response to the dismantling of the welfare state and the retrenchment of the state's regulatory authority, cities seek to attract increasingly mobile investment capital through amenity-based development in order to maintain financial solvency. Though the entrepreneurial city is by no means a new phenomenon, the need for municipal-scale revenue-generation intensified with the neoliberal turn (Hackworth, 2007). Fueled by municipal development subsidies and growth-management policies, investors identify development opportunities in persistently devalued inner-city areas (Dawkins and Nelson, 2003; Hackworth and Smith, 2001). In recent years, this "revitalization" of urban cores around the country has been celebrated as a "return" to the city; those more critical of the process describe it as a "revanchist" move to reclaim urban space from low-income people of color (Smith, 1996).

Such (re)development is inherently uneven; investment in one area goes hand in hand with another area's devaluation. As capital returns to the urban core, disinvestment and time take a toll on suburban housing stock and infrastructure (Hackworth, 2007). The loss of affordable housing in the inner city has driven many working residents and people of color from inner-core neighborhoods to these now-devalued suburbs, a process accelerated by the reinvention of urban neighborhoods to pander to the aesthetic tastes of the "creative class" (Hanlon, 2009; Katz, Creighton, Amsterdam, and Chowkwanyun, 2010; Kneebone and Garr, 2010; Peck, 2005). The prevalence of this spatial "seesawing" of capital - and resulting displacement of working-class residents and households of color from urban centers - leads Smith (2002, p. 446) to call gentrification a "consummate expression of neoliberal urbanism."

In recent years a discourse of "sustainability" (with its tripartite objectives of economic growth, social equity, and environmental quality) has often accompanied reinvestment in the urban core. So-called green projects, such as redevelopment of brownfields and installation of public transit and bike infrastructure, respond to environmental concerns that have gained traction since the 1970s. But such green urban redevelopment schemes are also central to entrepreneurial efforts of so-called sustainable cities to attract affluent, well-educated, environmentally minded 
residents and the businesses that cater to their tastes, constituting what While et al. (2004) have dubbed the "urban sustainability fix". Privileging economic growth over equity, such eco-friendly initiatives earn lucrative premiums from their sustainability branding and lay the groundwork for further accumulation via whatever development follows in its stead, green or not, thereby forestalling crises at the municipal level. But as more and more lower-income households and people of color are displaced to disinvested peripheral areas, it becomes clear that crises have been shifted to the household and neighborhood scale (Bunce, 2009; Checker, 2011; Dooling, 2009).

The structural dynamics described here help explain variegated landscapes of affluence and abandon in cities throughout the United States. Further, they are key to understanding the politics and sociocultural processes that uphold and challenge uneven development. Despite its claims of exceptionalism and laurels as a paradigmatic sustainable city, Portland is no exception. We now focus on three periods of Portland's history to illustrate how cycles of investment and disinvestment have left a legacy of racially- and spatially-explicit disparities, arguably exacerbated rather than mitigated by the city's sustainability efforts.

\section{Suburbanization and segregation in Portland: 1940s to 1970s}

The period encompassing post-war suburban development in East Portland on the one hand, and segregation and devaluation in Portland's Albina district on the other, aligns with the nationwide trends described above. By the Second World War, Portland emerged as a regional hub of economic activity through a mix of "ambition, boosterism, and canny entrepreneurship" (Abbott, 2011, p. 22). As in other cities along the Pacific Coast, Portland's waterfront and inner industrial area became an epicenter of shipbuilding, attracting workers from around the country. But prosperity was short-lived. As the war came to an end, Portland's shipyards closed and veterans returned home; upticks in inflation and unemployment levels soon followed (ibid.).

As elsewhere, wartime capital accumulation via industrial production switched to construction, real estate, and other sectors associated with mid-century suburbanization. From 1950 to 1980, over 300,000 new housing units were constructed in the Portland metropolitan area (see Table 2), many of these on Portland's periphery. Multnomah County began to strategize about how to bring some semblance of control to the suburban growth. Many County residents preferred policies - such as zoning - that protected property-owner interests and did not require a tax increase or excessive government oversight (Abbott, 1983, 1987; Lycan, 1987). In 1952, the County's efforts culminated in the adoption of zoning standards and building codes that favored new construction.

As an alternative to a municipal government, residents of unincorporated Multnomah County also opted for special service districts, autonomous pseudo-governmental institutions set up to handle basic regulation. Oversight by such districts "promised minimal public interference with private activity" (Abbott, 1983, p. 235). The districts were "almost invisible governments ... easily controlled by cliques of suburban businessmen, crossroads cronies, and new householders eager to hold down property taxes" (ibid.). This suburban growth coalition brought government officials and local residents together in the push for spatial regulation of particular forms of development, while assuring stable property values and investment potential. 
POST-PRINT VERSION - Goodling, Green, \& McClintock - Urban Geography (2015)

Table 2. Change in concentration of housing units between Portland and Multnomah County, 1940-1980.

\begin{tabular}{lcccc}
\hline Year & Portland & $\begin{array}{c}\text { Housing Units } \\
\text { Rest of } \\
\text { Multnomah County }\end{array}$ & Total & $\begin{array}{c}\text { Portland share of housing } \\
\text { units }\end{array}$ \\
\hline 1940 & 102,745 & 22,302 & 125,047 & $82.2 \%$ \\
1950 & 131,413 & 31,628 & 163,041 & $80.6 \%$ \\
1960 & 143,041 & 46,507 & 189,548 & $75.5 \%$ \\
1970 & 151,114 & 57,157 & 208,271 & $72.6 \%$ \\
1980 & 167,911 & 78,224 & 246,135 & $68.2 \%$ \\
\hline
\end{tabular}

Source: Census of Housing, 1940-1970 (U.S. Census, 1980a); Summary Tape File 3 (U.S. Census, 1980b)

During the height of national suburbanization trends in the 1960s, White Portlanders moved outward in all directions with the help of federal funding that expanded freeways and FHA loans that facilitated the purchase of newly constructed homes. The most affluent of these émigrés moved to the west and south of Portland, while more than twice as many - mainly those of more modest means - migrated eastward. Low- and mid-priced ranch-style tract housing continued to fill in pockets in both the inner and outer eastside from 1945 to 1960; neighborhoods from $60^{\text {th }}$ Street eastward to $148^{\text {th }}$ Street gained 30,000 residents alone. Many of these residents remained intimately connected to the central city, however, through both employment and social ties; in the 1960 s, roughly $65 \%$ of unincorporated Multnomah County workers commuted into the city (Abbott, 1983,1987; Lycan, 1987).

As in other cities around the United States, the switching of capital from industry to real estate - and from the central city to suburbia - meant a "hollowing out" of the middle-class tax base, and a consequent dearth of funding for central city maintenance and development. While Portland's White households moved outwards in the post-war years, African Americans possessed few locational choices. Portland's African American population had grown from about 2,000 to 20,000 during the war years, many arriving from Chicago and New York to work in the shipyards. Most were immediately subjected to overt segregation in inner Portland's Albina district (Abbott, 2011; Gibson, 2007).

Racist segregation, housing discrimination, and displacement of African Americans in Portland closely followed a script playing out in cities across the country. Institutional discrimination had been ongoing since 1919, when Portland's Realty Board established a "code of ethics" that stated that realtors were subject to dismissal for selling real estate to African Americans outside of the Albina neighborhoods. This policy remained officially in place until the mid-1950s, but was unofficially carried out until at least the late-1980s (Lane, 1990). Racial covenants thus kept homes in many neighborhoods off-limits to people of color, and insurance redlining blocked mortgage lending in so-called "high risk" areas where African Americans and low-income immigrants lived.

In the 1950s and ' 60 s, neglect by absentee landlords and a general lack of capital investment spelled devaluation of Albina's housing stock and infrastructure, the start of a wave of "blight clearance" policies that seriously disrupted African American households and neighborhoods, and the emergence of a growing rent gap (Gibson, 2007). Throughout the 1960s 
and ' 70 s, federally funded urban renewal projects leveled acres of African American homes and businesses in order to make room for projects such as Emanuel Hospital. ${ }^{3}$ Likewise, in an effort to lure capital back to the central city, elected officials committed City funds to constructing the Memorial Coliseum, and private investors to building Lloyd Center Mall.

\section{Growing pains: 1970s to 1990 s}

A second period of capital-switching central to Portland's uneven development lasted roughly from the 1970s into the early '90s. This period encompasses the City's annexation of East Portland's land and residents - and tax base - and the continued devaluation of upper Albina and sustained redevelopment of lower Albina. In the 1940s, Planning Director Harry Freeman had predicted that suburban sprawl would lead to difficulties in taxation and utility provision, due to shifting populations and leapfrog subdivision of land (Abbott, 1983). By the 1970s, City leaders were echoing Freeman's concern about demographic shifts and infrastructural challenges associated with suburbanization, as middle-class taxpaying households exited the city. Officials pursued a "population strategy" in an effort to boost tax rolls to fund infrastructure and municipal services.

Such tactics, however, implicitly maintained the institutional racism undergirding earlier devaluation of Albina. City leaders justified the urban renewal projects that continued to decimate parts of African American neighborhoods by implying that Portland's "livability" was hindered by the presence of certain groups, including African Americans:

Increasingly, [Portland] is becoming a community of extremes populated by the young and the old, the lower income and unemployed, minorities and renters. While these trends might not be peculiar to Portland, what may be different here is the opportunity to arrest them before the damage becomes permanent and irreversible. There is a sense among the citizens and elected leaders of the city that Portland's heritage of livability is too valuable to be lost. There is a sense that a coherent, coordinated, purposeful strategy may be able to preserve and protect the city and keep it America's most livable city in the future. (Webber, 1977)

Such thinly veiled aversions to households that did not fit the White, middle-class, home-owning ideal of revenue generation guided many public sector decisions on taxation and efforts to maintain low crime rates and high environmental standards.

Similar stances also steered private sector lending procedures. Despite progressive legal changes attempting to expand African Americans' abilities to build wealth through homeownership, de facto segregation and disinvestment continued apace in Albina through the '80s. For example, as late as 1988 - a decade after the federal Community Reinvestment Act required equal lending practices - banks did not make a single federally-insured mortgage in Portland's four census tracts with the highest African American populations, even though such mortgages posed virtually no risk to lenders. One resident turned down for a loan reflected, "It's redlining without redlining" (quoted in Lane, 1990). This widened the rent gap, setting the stage

\footnotetext{
${ }^{3}$ See Loving (2011) for a detailed account of displacement of businesses from the Albina area as a result of city policies.
} 
for the public subsidization of private development at the expense of longtime African American residents.

Freeman's prediction of suburbanization's negative impacts applied to outlying areas, as well. The small-scale suburban subdivisions that emerged east of $82^{\text {nd }}$ Avenue in the late $1940 \mathrm{~s}$ and early 1950s began to overwhelm infrastructural capacity. In the 1970s, Oregon's Department of Environmental Quality warned that it would mandate a new sewer system in the 22,300 acres of unincorporated land between Portland and Gresham (the city's eastern neighbor) to mitigate overburdened septic fields. Further, Portland officials felt that the City's water supply was at risk, as it had previously drilled wells in the unincorporated area as a backup source. Portland and Multnomah County officials alike argued that the County would be unable to shoulder the high cost of connecting to the municipal sewer system (Lansing and Leeson, 2012). The inadequate septic system served as the basis for calls for Portland to annex unincorporated "East County".

Prefiguring the sustainability paradigm that would take hold in Portland, the desire for economic growth and environmental regulation found common ground in annexation. Portland's bid built on momentum of the so-called "freeway revolt", in which a handful of progressive, environmentally-minded leaders pushed back against construction of a network of freeways outlined in Robert Moses' 1943 plan for Portland. Mayor Neil Goldschmidt was particularly fearful that the proposed east-west Mt. Hood Freeway would interfere with efforts to rejuvenate downtown Portland. County Commissioners Don Clark and Mel Gordon aligned with Goldschmidt, and were able to successfully help block the project in 1974 (Bonner, 2000). By this point, City leaders had grown disillusioned with the capacity of Multnomah County planners to control growth in ways that benefited Portland's interests, and those opposed to freeway expansion recognized that annexation would strengthen the City's position "in dealing with the [state] Legislature on land use issues by converting legislators in the districts in mid-county into city stakeholders" (former Multnomah County Executive Dennis Buchanan, quoted in Bonner, 2001). Portland thus began its controversial policy of "vigorous annexation" in order to sway suburban growth patterns, while also securing access to the area's tax base (Abbott, 1983; Lansing and Leeson, 2012). ${ }^{4}$ A 1978 Portland State University study commissioned by the City calculated that annexation would bring in \$24.4 million in additional annual tax revenue, while costing the City $\$ 18.4$ million for services (Hart, 1981b).

Many unincorporated Multnomah County residents opposed annexation, suspecting that City officials were simply using them to bolster its tax base (Lansing and Leeson, 2012). An Oregonian article captured the sentiments of at least one angry resident, who bluntly stated, "That whole Portland [annexation] operation is a professional rip-off" (Hart, 1981a). Others, however, were eager for the city to take the area under its wing. In another interview, one landowner explained, "I want to be with the city of Portland, rather than dealing with an unknown quantity ... We've got investors who want to develop our property" (Hart, 1981b). Other proponents of annexation included a growth coalition of city council members, county commissioners, bankers, and developers, eager to capitalize on development projects, but also to respond to an increasingly progressive public's demand to mitigate the environmental costs of suburbanization. They succeeded in securing the highly contested addition of 115,000 residents in a thirty square

\footnotetext{
${ }^{4}$ Portland had performed over 200 small annexations in the 1960s and continued this trend for the next two decades. The average parcel size was forty acres, however, with mean populations of less than eighty people per parcel (Abbott, 1983), a scale much smaller than the annexation that was to follow.
} 
mile area of present-day East Portland in 1983; another massive annexation followed eight years later. In the end, the city annexed roughly a quarter of the city's current landmass - and tax base during the 1980s and early '90s (City of Portland, 2007).

\section{Sustainability fix: 1990 s to present}

In balancing the City's budget in part through annexation, leaders addressed some of the financial hitches of the "shifting-population problem" to which Freeman alluded back in the "40s. At the same time, the devalued Albina district was becoming fertile ground for redevelopment and an urban sustainability fix. To understand the shift from aggressive annexation of East Portland to its relative decline, we turn to processes occurring during a third period of capitalswitching beginning in the 1990s: the increased flow of public and private capital into Albina and other inner core neighborhoods, on one hand, and the differential neglect of East Portland, on the other.

The roots of Portland's sustainability fix lie in Oregon's stringent land use laws, which include requirements for urban growth boundaries (UGBs). Established in the late 1970s to protect prime agricultural land and curb sprawl, these conservationist growth management policies have, in part, helped to redirect growth inward, prioritizing urban densification over extensive suburbanization. ${ }^{5}$ But perhaps most importantly, Portland's UGB has given the city a certain cachet as an environmentally progressive place to live, helping the city to attract investment capital and more affluent residents. In the words of the Bureau of Planning and Sustainability Director Susan Anderson, "We're not doing [sustainability] just to be altruistic ... there's money to be made" (quoted in Minow Smith, 2012).

The public role in the redevelopment of the urban core has not been restricted to regulation alone. In addition to the UGB, transit-oriented development and in-fill construction have transformed warehouses into lofts, and vacant lots into stylish, LEED-certified condos and retail hubs, contributing to Portland's international reputation for commitment to livability and sustainability. In 1991, Portland's City Council adopted the Albina Community Plan (1993) with a goal of beautifying the district's streets and sidewalks, developing several of its 2,000+ vacant lots, and providing loans for storefront improvements along a handful of dilapidated historic business corridors (Gibson, 2004). Public funds, particularly through Albina's Interstate Corridor Urban Renewal Area (URA) tax-increment financing, subsidized these changes (Gibson, 2004; Gibson and Abbott, 2002).

A central feature of the Interstate URA was the light-rail line that opened along Interstate Avenue in 2004. This direct transit route downtown and the abundance of quaint - and cheap historic single-family homes, lured legions more newcomers to Albina. Despite early promises that increasing property values along the light rail line would "benefit existing residents and protect against gentrification and displacement" (Scott, 2012), however, a tax-activist lawsuit against the Portland Development Commission halted most precautionary anti-displacement measures the same year (ibid.).

Along with the foreclosure crisis, such developments have accelerated the process of displacing Albina's African American residents; housing prices climb as older housing stock is

\footnotetext{
${ }^{5}$ Clark County, just across the state line in Washington, has grown in a particularly sprawling fashion, however, leading some to argue that it has acted as a "safety valve" for developers and population.
} 
renovated and new in-fill constructed, changing the cultural character of the neighborhood and forcing out longtime residents (Bates, 2013; Gibson, 2004; Preston, 2012). In some cases, tenants of entire housing complexes and apartment buildings have been evicted so that owners can make improvements and raise rents or convert them to condos for sale (Scott, 2012). In some Albina neighborhoods, housing prices tripled between 1990 and 1996 (Gibson and Abbott, 2002), and have continued apace ever since (CLF 2013).

But gentrification is not only the result of rising home prices and other direct forms of displacement. The "class-remake of the central urban landscape" (Smith 1996, p. 39) is also an indirect process that includes the loss of place, cultural resources, and community (Davidson, 2008; Marcuse, 1986). Although plans implied that development would benefit longtime African American residents, coffee shops and yoga studios catering to an incoming White "gentry" opened up on historically Black Alberta Street within a few years (Sullivan and Shaw, 2011); North Mississippi and North Williams Avenues have been transformed in a similar manner. Brewpubs and bike shops have opened alongside brand new condo complexes with names like Eco Flats PDX. Marketing tag lines advertising "Sustainable Urban Living in Portland” cater to a predominantly White, eco-conscious population. At the same time, many of Albina's lightindustrial businesses and Black-owned stores and have moved or gone out of business (Parks, 2013; Sullivan and Shaw, 2011). In 2012, Carl Talton, former Portland Development Commission chair told the Portland Monthly, "We anticipated gentrification and welcomed it to a degree. What we didn't anticipate was that we wouldn't be able to manage it and that it would just run away" (quoted in Gragg, 2012).

The sustainability fix in Portland is very much a spatial one; as capital returned to inner Portland under the banner of sustainability, livability, and neighborhood revitalization, devaluation of East Portland's built environment ensued - even as population increased. But the seesaw of investment and disinvestment is not as cut-and-dry as Smith and Harvey might suggest. Rather, reinvestment and gentrification in inner Portland has been accompanied by piecemeal development in East Portland in the decades following annexation. East Portland's sprawling urban form - a legacy of the post-war, automobile-centered suburban development - was ideal for cheap infill development. Moreover, lax enforcement of building codes, regional growth policies and state tax laws, and inner-core reinvestment all foregrounded the relative devaluation of East Portland's built environment - and the rise of a population living below the poverty line in the area.

At least initially, the City recognized the infrastructural challenges annexation would bring, and planned accordingly. The 1996 Outer Southeast Community Plan authorized higher density zoning in East Portland, and, along with the other plans, such as the earlier 1980 Banfield Light Rail Transit Station Area Planning Program, anticipated many of the growth-related challenges: between 1996 and the mid-2000s, the area east of $82^{\text {nd }}$ Avenue absorbed nearly $40 \%$ of Portland's new housing units, mainly inexpensive multifamily apartments (City of Portland Bureau of Planning, 1996; City of Portland Bureau of Planning, 2007). Such plans articulated multiple approaches to improving infrastructure through upgrades, encouraging transit-oriented development, and increasing environmental protections.

And yet, despite preexisting concerns over urban services, the influx of housing units, a vocal body of East Portland activists (e.g., East Portland Action Plan Committee), and three decades of tax revenue that should have funded improvements, the City has yet to provide the 
same level of infrastructure to East Portland as it has to the rest of the city. ${ }^{6}$ In fact, East Portland receives less City spending from all bureaus except police and fire and ranks lowest in the city in almost every "livability" category, from access to transit and parks to traffic fatalities and nighttime safety (City of Portland Bureau of Planning, 2007; Griffin-Valade, Kahn, and Scott, 2014; CLF, 2013).

The unevenness of Portland's built environment can be traced, in part, to inconsistent application of planned infrastructure improvements, arising from a combination of factors: a City policy that decentralizes infrastructure payment mechanisms; developer intransigence; and political indifference on the part of City leaders, due in part to its unique at-large system of city commissioners. ${ }^{7}$ One of the principal ways that the City has funded infrastructure in East Portland is through Local Improvement Districts (LIDs), which require that property owners pay for street paving, sidewalks, and stormwater drainage systems adjacent to their homes. Since annexation, many developers have failed to meet LID requirements, and the City has not consistently enforced them (City of Portland Bureau of Planning, 2007). The result is a haphazard mosaic of old and new construction, incomplete sidewalks, gravel cul-de-sacs, potholes, and unpaved streets. ${ }^{8}$

In addition to a decentralized system of infrastructure improvements, state tax measures have generally constrained spending on infrastructure maintenance and construction. Measure 5, passed in 1990, established a hard ceiling on a district's potential revenue from property taxes. The measure set a limit on the amount that individual property-holders could owe: $\$ 5$ per $\$ 1000$ for school districts and $\$ 10$ per $\$ 1000$ for general governmental taxes. Measures 47 and 50, passed in 1996, reduced the assessed value of every property to $90 \%$ of its $1995-96$ rate, limited annual growth of assessed value to $3 \%$ for properties developed prior to 1995-96, and prohibited properties from having an assessed value greater than its real market value (Law, 2013c; Oregon Department of Revenue, n.d.).

These three measures relieved the tax burden for owners of older homes but placed a heavier tax burden on those owning newer properties. Older homes in the gentrifying Albina neighborhood - whose market values skyrocketed between 1995 and 1998 - are therefore taxed less than East Portland's newer homes, whose values remained flat during the same period. In essence, in addition to constraining the city's capacity to raise revenue for infrastructural improvements, these state tax measures have resulted in inner Portland residents paying significantly lower property tax rates than East Portlanders; in almost all neighborhoods west of

\footnotetext{
${ }^{6}$ Even federal funds have failed to make their way east of $82^{\text {nd }}$; when federal stimulus funding was distributed during President Obama's first term, for example, less than 1\% of Portland's share was invested in East Portland (Mirk, 2010).

${ }^{7}$ Notably, Portland is the remaining large city in the U.S. to have a commission form of government, in which commissioners have legislative, administrative, and quasi-judicial powers and are elected at-large rather than by district. As a result, East Portland residents lack the political power that a district or ward system might afford (Schmidt, 2014).

${ }^{8}$ Furthermore, many East Portland multifamily apartment complexes themselves are of poor quality: according to a recent City auditor's report, for example, complaints of mold in rental units are higher in East Portland than the rest of the city, in large part due to a prevalence of cheaply constructed metal windows and baseboard heating (Griffin-Valade, Kahn, and Gavette, 2013).
} 
$82^{\text {nd }}$, the share of property value on which owners pay taxes ranges from 1 to $60 \%$, while east of $82^{\text {nd }}$, it rises to between 80 and $100 \%$ for the vast majority of properties (Law, 2013c). ${ }^{9}$

This history illustrates the uneven development arising from Portland's sustainability fix. Policy and politics coupling growth and greening guided differential flows of investment; new additions to the built environment were laid upon older strata, themselves shaped by sociocultural relations of the preceding decades. While some earlier decisions were overtly racist (e.g., redlining and housing covenants), it is unlikely that there was some insidious plan to deprive East Portlanders of infrastructural improvements while charging a higher tax rate. But this has been the de facto result, where tax revenues actually gravitate from the periphery of the city to its core.

\section{(Ware)housing the poor}

Cycles of capital investment and disinvestment are not only linked to changes in the urban form, but also to demographic shifts. In the case of Portland, the demarcated devaluation of East Portland's built environment - within a context of regional housing dynamics hostile to affordable housing construction - has helped to concentrate poverty in East Portland. East Portland's piecemeal urban development has left spaces ripe for construction of cheap, lowquality multifamily housing construction in areas previously dominated by single-family homes. While this approach has limited sprawl, it has also helped to concentrate poverty.

In direct violation of requirements of the federal Fair Housing Act, low-income renters receiving governmental support in metropolitan Portland have been systematically placed in the region's most impoverished, segregated census tracts. ${ }^{10}$ Under both the state-run rental assistance program and the county-led Section-8 voucher program, for example, over half of African American and Latino renters in recent years were placed in units in census tracts with a poverty rate greater than $20 \%$, most of which are located at the city's fringes, particularly in East Portland. In addition to a high concentration of subsidized renters, a disproportionate number of lowerincome and working-class renters who do not receive subsidies also reside in East Portland (Schmidt, 2012).

The concentration of renters did not occur solely because of East Portland's low-density suburban form. New construction of multifamily units east of $82^{\text {nd }}$ is due to a suite of factors. Several suburban municipalities have refused to allow affordable housing units - particularly

\footnotetext{
${ }^{9}$ Due to the age of housing stock and historical disinvestment in Albina and other inner-core neighborhoods, the 1995 assessed values (in contrast to rapidly climbing market value) of homes in those neighborhoods were depressed compared to East Portland. In recent years, however, the median home price in 5 of the 6 zip codes east of $82^{\text {nd }}$ was more than $\$ 150,000$ lower than the citywide median home price (City of Portland, 2009). Notably, this area also has substantially higher rates of high-cost conventional mortgages as well as foreclosures than other parts of the city (ibid.). Moreover, the only census tracts to lose median home values in the city between 2000 and 2010 were in East Portland. In contrast, some tracts in lower Albina saw their median home values increase 100\% (CLF, 2013).

${ }^{10}$ The three-county Portland Metro region (Multnomah, Clackamas, and Washington counties) receives approximately $\$ 170$ million in housing support annually from the Department of Housing and Urban Development in the form of support for county housing authorities that oversee Section-8 voucher distribution, state-administered federal tax credits for affordable unit construction, and federal block-grant funds that can be directed towards housing projects (Schmidt, 2012). In accepting these funds, the county, city, and state are obligated to conform to the Act, which stipulates that affordable housing must be evenly distributed across the city, and that it must not be placed in areas of concentrated poverty or encourage racial segregation.
} 
multifamily housing - within their city limits (ibid.). While state law requires the construction of multifamily housing, many municipalities neighboring Portland have invested mainly in high-end multifamily housing or have allowed for single-family housing development on land zoned for multi-family. Metro, Portland's elected regional government in charge of land use decisions, attempted to impose a "fair share" affordable housing policy in the mid-90s at the behest of progressive regional housing coalitions, and threatened to impose inclusionary zoning regulations if the voluntary fair share policies failed to increase the supply of affordable housing (Provo, 2009). The threat of inclusionary zoning, however, backfired, spurring a suburban and homebuilder revolt which culminated in a statewide ban on inclusionary zoning, leaving only weak regional voluntary affordable housing measures (ibid.). Furthermore, in 2002, these suburban municipalities passed an amendment to the Metro charter prohibiting Metro from requiring increased density in single-family zoned neighborhoods (Metro, 2003). Finally, it was legal for landlords to openly refuse Section- 8 voucher holders in the state of Oregon until the summer of 2014. As a result of these multiple obstacles, East Portland has absorbed much of the region's relatively lower-cost units and lower-income families.

Table 3. Socioeconomic indicators (absolute numbers) and proportions (\%) of total city population for all of Portland, East Portland, and the rest of Portland, 2000-2010.

\begin{tabular}{cccccccccc}
\hline & \multicolumn{3}{c}{ Portland } & \multicolumn{3}{c}{ East Portland } & \multicolumn{3}{c}{ Rest of Portland } \\
& 2000 & 2010 & $\begin{array}{c}\% \\
\text { change }\end{array}$ & 2000 & 2010 & $\begin{array}{c}\% \\
\text { change }\end{array}$ & 2000 & 2010 & $\begin{array}{c}\% \\
\text { change }\end{array}$ \\
\hline $\begin{array}{c}\text { Total } \\
\text { population }\end{array}$ & 543,057 & 598,548 & 10.2 & 162,212 & 186,828 & 15.2 & 380,844 & 412,120 & 8.2 \\
& & & & & & & & & \\
Living in & 68,972 & 90,749 & & 21,504 & 33,461 & & 47,468 & 57,288 & 20.7 \\
poverty & $12.7 \%$ & $15.2 \%$ & 31.6 & $13.3 \%$ & $17.9 \%$ & 55.6 & $12.5 \%$ & $13.9 \%$ & \\
College & 122,369 & 169,193 & 38.3 & 15,570 & 23,440 & 50.5 & 106,799 & 145,753 & 36.5 \\
educated & $22.5 \%$ & $28.3 \%$ & & $9.6 \%$ & $12.5 \%$ & & $28.0 \%$ & $35.4 \%$ & \\
\hline
\end{tabular}

Source: LTDB, 2013

The simultaneous pull of cheap shelter in outer East Portland and push of rising rents and sale prices in inner Portland have had major demographic - and socio-cultural - implications for the city. Over the last decade, East Portland has absorbed new residents more rapidly than the rest of the city - accounting for approximately 44\% of Portland's population growth from 2000 to 2010 (see Table 3). In sharp contrast to the rising incomes and shrinking diversity in the majority of census tracts west of $82^{\text {nd }}$ Avenue, however, East Portland is now home to the city's least affluent and most diverse population. ${ }^{11}$ East Portland's residents of color increased a full $68 \%$ between 2000 and 2010 (LTDB, 2013). Newcomers have joined dwindling numbers of lower-tomiddle income Whites who have lived in East Portland for years, many since the early days of post-war suburbanization and others displaced by earlier waves of gentrification that affected low-income neighborhoods around NW $23^{\text {rd }}$ Avenue and SE Hawthorne (CLF, 2013).

${ }^{11}$ Notably, the census tract with the lowest Median Household Income $(\$ 25,022)$ in East Portland (Tract 83.01 ) is also the most diverse in the city, with a 54\% non-White population (ACS, 2008-2012). 
Most of these newcomers to East Portland fall into one of two categories: immigrants and refugees moving from Mexico, the former Soviet Union, Somalia, Ethiopia, Bosnia, Vietnam, and Cambodia; and low-income residents displaced by rising rents in other parts of Portland (HannahJones, 2011; Schmidt, 2012). Immigrant numbers in Portland grew by 136\% between 1990 and 2000 , double the growth rate for the nation. Refugee settlement programs in East Portland are partly responsible for the concentration of immigrants (Hardwick and Meacham, 2008; Hume and Hardwick, 2005). They have been joined by a growing number of African Americans, many of whom are intra-city migrants, moving from gentrifying areas in and around Albina (Krishnan, 2012). Indeed, as much as $70 \%$ of some inner North and Northeast census tracts were made up of African American residents in 1970, whereas 40 years later we see a dramatic dispersal (see Figure 3). Notably, some tracts have lost over a third of African American residents since 2000. Lyrics by Portland rapper Luck-One (2011), reprinted in this paper's epigraph, poignantly summarize the lived experience of Portland's uneven development and, more broadly, the social cost of an urban sustainability fix.

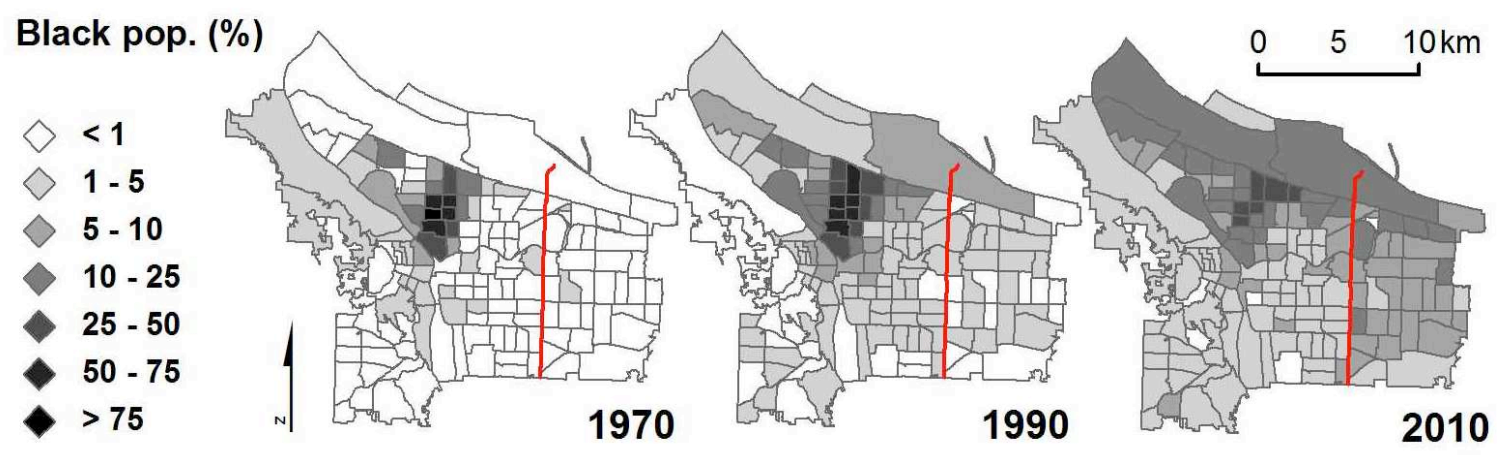

Figure 3. Portland's African American population has steadily declined in Albina and markedly increased in neighborhoods on the outskirts of the city from 1970 to 2010 . The most dramatic increases have occurred in East Portland. Data source: LTDB, 2013.

\section{Conclusion: From uneven development to just sustainability?}

Portland, like all cities, has long had its haves and have-nots. Abbott (2011, p. 116) describes 1930s Portland as "two cities side by side. Militant union members, skid-row workers, and the periodically unemployed were the labor force that kept Portland factories and docks in motion. Middle-class visitors saw a different city - solid, sober, politically and socially conventional." While today's visitors might witness - and indeed come to celebrate - the city's seemingly progressive politics and ethos of sustainability, disparities between "two cities side by side" endure, albeit in a different socio-spatial configuration and at a fundamentally different scale than in years past. As we have attempted to show here, understanding how two such cities can coexist within the same municipal boundaries - and how a standard bearer of sustainability can also include a sprawling, neglected suburbia - demands empirical examination of the structural processes of uneven development occurring across space and time. Moreover, it demands understanding the co-production and functional interdependence of the two: the rise of one's built environment has depended on its counterpart's decline; the influx of an affluent population has accompanied the dislocation of a poor one. Indeed, the insights of Engels (1872) 
are still germane: "The breeding places of disease....in which the capitalist mode of production confines our workers... are not abolished; they are merely shifted elsewhere!"

Critical urban geographers have long recognized that the particularities of urban form, racialized poverty, and population distribution across regions both shape and are shaped by cycles of capital accumulation and devaluation, largely facilitated by planning decisions and policies. Despite Portland's green exceptionalism, the processes of demarcated devaluation shaping postwar urban and suburban landscapes are no less prevalent in of the paradigmatic sustainable city. We have shown how three periods of capital-switching mark distinct phases of (uneven) development, inseparable from waves of demographic change; East Portland's present-day devaluation is not only the product of particular planning and policy decisions at multiple scales, but it is intimately connected to Albina's historical segregation of African Americans, devalorization of the built environment, and eventual rent gap and influx of capital in the form of a sustainability fix.

Totalizing discourses of sustainability and livability belie the fact that not all Portlanders benefit from the purported rising tide of sustainable development. But more to the point, the differential conditions and outcomes we highlight here did not materialize overnight. In an interview with the Portland Mercury in 2010, then-Portland mayor Sam Adams commented, "Every part of the city has improved in terms of the rate of poverty, except for East Portland" (quoted in Mirk, 2010). Adams attributed this disparity to a dearth of basic infrastructure installed by Multnomah County when the area was an unincorporated - but growing - hinterland. But this explanation only hints at the confluence of factors that have carved a stark line between East Portland and much of the rest of the city. After all, most of East Portland was incorporated into the City of Portland over thirty years ago, and "improvement" in Albina has spelled the dislocation of thousands of African Americans. The processes by which planning and policy decisions aggregate to structure serious disparities across race and space cannot be ignored.

In contrast to Adams' facile explanation, Harvey (1989, p. 54) summarizes, "It is through urbanization that the surpluses [i.e., profits] are mobilized, produced, absorbed, and appropriated and...it is through urban decay and social degradation that the surpluses are devalued and destroyed." Cycles of development and devaluation take time; land must become sufficiently devalued for profit to become possible. Understanding the current landscape of disparities therefore requires that we look to the past to identify the capitalist seesaw of investment and disinvestment, one that set the stage for developers to profitably inject Albina with capital, and create the necessary conditions for the displacement of lower-income households and residents of color from inner-core neighborhoods to East Portland.

We should also look to the past to better understand the implications of various approaches to redressing disparities. There is no shortage of well-meaning, progressive intent in the ranks of Portland's leaders. In part due to a long tradition of local organizing and agitation around the serious institutionalized racism of past and present plans and policies in Albina and the dearth of infrastructure and growing concentration of poverty in East Portland, City leaders have vowed to take a more "equitable" approach to development. For example: the 2012 Portland Plan employs an explicit equity lens in laying out a 25-year vision for the city; the City's Bureau of Planning and Sustainability in 2013 commissioned a study of neighborhoods most at risk of gentrification; and City officials have made moves to improve transit service, pedestrian and bike infrastructure, and parks and community center access for East Portland residents (Bates, 2013; City of Portland, 2012; Goodling and Herrington, 2014; Law, 2013a, 2013b). 
Yet, there is the risk of falling back on old models. We do not dispute the need for infrastructural improvements, but there is a danger in approaching the problems of poverty and gentrification/displacement at the scale of individual blocks and even individual neighborhoods or urban renewal areas, as resources invested or withdrawn from one area can have serious reverberations in another. Without a firm grasp of the historical conditions that produced greater concentrations of racialized poverty in East Portland, plans and policies intended to reverse disparities risk being palliative at best, and may even reinforce the mechanisms that precipitate poverty and displacement of poor and minority households.

But despite Portland's checkered past, future development trajectories are not predetermined. Adoption of a multi-pronged anti-displacement approach could put Portland on the map as a livable city for all. Such efforts might range from development-scale projects, such as community benefits agreements that include living wage jobs, to broader structural changes, including transferring equity-oriented visions laid out in the 2012 Portland Plan to the legallybinding Comprehensive Plan currently under revision, or instituting policies that shift land out of the speculative market for permanently affordable housing (Bates, 2013). Several local grassroots organizations are beginning to rally around such approaches.

As wealthier residents begin to move into the now-devalued ranch houses and bungalows tucked beneath towering Douglas firs in certain neighborhoods just east of $82^{\text {nd }}$ Avenue, however, a veritable "fourth wave" (Hackworth and Smith, 2001) of suburban gentrification and a new "leading edge of larger processes of uneven development" (Smith, 1982) is already underway, even as displacement from Albina rapidly continues (Bates, 2013; Law, 2013b). A local organization, Coalition for a Livable Future (2007, p.24), argues that we must "begin to recognize localized changes that have regional consequences - and not just 'move' poor populations across the region." But charting an alternative path forward toward a more just sustainability demands that, in order to heed this advice moving forward, we first look to the past.

\section{Acknowledgements}

All authors contributed equally. We extend our warm thanks to Sy Adler, Henrik Ernstson, and three anonymous reviewers for comments on earlier drafts of the manuscript, and to Dillon Mahmoudi for his assistance with census data. Thanks are also due to Carl Abbot and Karen Gibson for talking through historical details, and to the organizers and participants of the "From Dreamscape to Nightmare? The Life, Death and Resurrection of Suburbia in the $20^{\text {th }}$ and $21^{\text {st }}$ Century" sessions at the 2013 Meeting of the Association of American Geographers in Los Angeles. All remaining errors are our own.

\section{Funding}

This material is based upon work supported by National Science Foundation (NSF) IGERT Grant \#0966376: "Sustaining Ecosystem Services to Support Rapidly Urbanizing Areas". 


\section{Works Cited}

Abbott, Carl (1983). Portland: Planning, Politics and Growth in a Twentieth-Century City. Lincoln, NE: University of Nebraska Press.

Abbott, Carl (1987). The Everyday City: Portland's Changing Neighborhoods. In Larry Price, editor, Portland's Changing Landscape. Portland: Portland State University Department of Geography and the Association of American Geographers.

Abbott, Carl (2011). Portland in Three Centuries: The Place and the People. Corvallis, OR: Oregon State University Press.

Bates, Lisa (2013). Gentrification and Displacement Study: Implementing an Equitable Inclusive Development Strategy in the Context of Gentrification. Commissioned by the City of Portland's Bureau of Planning and Sustainability. Retrieved from www.portlandoregon.gov/bps/article/454027

Beauregard, Robert (2006). When America Became Suburban. Minneapolis: University of Minnesota Press.

Berke, Philip, \& Maria Manta Conroy (2000). Are We Planning for Sustainable Development? Journal of the American Planning Association, 6(1), 21-33.

Bonner, Ernie (2000). Interview with Don Clark. Retrieved from www.pdx.edu/usp/planpdxorginterview-don-clark

Bonner, Ernie (2001). Interview with Dennis Buchanan. Retrieved from www.pdx.edu/usp/planpdxorg-interview-dennis-buchanan

Brenner, Neil, \& Nik Theodore (2002). Cities and the Geographies of Actually Existing Neoliberalism. Antipode, 34(3), 349-379.

Bunce, Susannah (2009). Developing Sustainability: Sustainability Policy and Gentrification on Toronto's Waterfront. Local Environment, 14(7), 651-667.

Checker, Melissa (2011). Wiped Out by the 'Greenwave': Environmental Gentrification and the Paradoxical Politics of Urban Sustainability. City \& Society, 23(2), 201-229.

City of Portland (2009). Portland Plan Housing Affordability Background Report. Retrieved from www.portlandonline.com/portlandplan/index.cfm? $\mathrm{a}=270879 \& \mathrm{c}=51427$

City of Portland (2012). The Portland Plan: Prosperous, Educated, Healthy, Equitable. Retrieved from www.pdxplan.com 
City of Portland Bureau of Planning (1993). Albina Community Plan (ACP). Retrieved from www.portlandoregon.gov/bps/article/58586

City of Portland Bureau of Planning (1996). Outer Southeast Community Plan. Retrieved from www.portlandoregon.gov/bps/article/88069

City of Portland Bureau of Planning (2007). East Portland Review. Retrieved from www.portlandonline.com/bps/index.cfm? $\mathrm{a}=177862 \& \mathrm{c}=44639$

Coalition for a Livable Future (CLF) (2007). The Regional Equity Atlas: Metropolitan Portland's Geography of Opportunity. Retrieved from www.equityatlas.org

Coalition for a Livable Future (CLF) (2013). The Regional Equity Atlas: Metropolitan Portland's Geography of Opportunity. Retrieved from http://clfuture.org/programs/regional-equityatlas/maps-and-analysis/

Curry-Stevens, Ann, Amanda Cross-Hemmer, \& Coalition of Communities of Color (2010). Communities of Color in Multnomah County: An Unsettling Profile. Retrieved from http://coalitioncommunitiescolor.org/docs/AN\%20UNSETTLING\%20PROFILE.pdf

Dale, Ann, \& Lenore L. Newman (2009). Sustainable Development for Some: Green Urban Development and Affordability. Local Environment, 14(7), 669-681.

Davidson, Mark (2008). Spoiled Mixture: Where Does State-Led 'Positive' Gentrification End? Urban Studies, 45(12), 2385-2405.

Dawkins, Casey, \& Arthur Nelson (2003). Statewide growth management policy and central city revitalization. Journal of the American Planning Association, 69(4), 381-396.

Dooling, Sarah (2009). Ecological Gentrification: A Research Agenda Exploring Justice in the City. International Journal of Urban and Regional Research, 33(3), 621-639.

Dyckhoff, Tim (2012). The Five Best Places to Live in the World and Why. The Guardian. Retrieved from www.guardian.co.uk/money/2012/jan/20/five-best-places-to-live-in-world

Engels, Friedrich (1872). The Housing Question. Retrieved from www.marxists.org/archive/marx/works/download/Marx_The_Housing_Question.pdf

Gibson, Karen (2004). Urban Redevelopment in Portland: Making the City Livable for Everyone? In Connie Ozawa, editor, The Portland Edge. Washington: Island Press, 61-83.

Gibson, Karen (2007). Bleeding Albina: A History of Community Disinvestment, 1940-2000. Transforming Anthropology, 15(1), 3-25.

Gibson, Karen, \& Carl Abbott (2002). City Profile: Portland, Oregon. Cities, 19(6), 425-436. 
Goodling, Erin \& Cameron Herrington (2014). Reversing Complete Streets Disparities: Portland's Community Watershed Stewardship Program. In Stephen Zavestoski \& Julian Agyeman, editors, Incomplete Streets: Processes, Practices, and Possibilities. London: Routledge, 176-201.

Gragg, Randy (2012). Black in Portland: 130 Years of Dislocation. Portland Monthly. Retrieved from www.portlandmonthlymag.com/news-and-profiles/history/articles/black-in-portland-march2012\#

Griffin-Valade, LaVonne, Drummond Kahn, \& Kristine Adams-Wannberg (2010). City of Portland: $20^{\text {th }}$ Annual Community Survey Results. Portland, Oregon: Office of the City Auditor.

Griffin-Valade, LaVonne, Drummond Kahn, \& Ken Gavette. (2013). Urban Services Policy and Resolution A: Core City Services Not Articulated; 30-Year-Old Commitments Obsolete. Portland, Oregon: Office of the City Auditor.

Griffin-Valade, LaVonne, Drummond Kahn, \& Jennifer Scott (2014). East Portland: History of City Services Examined. Portland, Oregon: Office of the City Auditor.

Gunder, Michael (2006). Sustainability: Planning's Saving Grace or Road to Perdition? Journal of Planning Education and Research, 26, 208-221.

Hackworth, Jason (2007). The Neoliberal City: Governance, Ideology, and Development in American Urbanism. Ithaca: Cornell University Press.

Hackworth, Jason, \& Neil Smith (2001). The Changing State of Gentrification. Tijdschrift voor Economische en Sociale Geografie, 92(4), 464-477.

Hanlon, Bernadette (2009). A Typology of Inner-Ring Suburbs: Class, Race, and Ethnicity in U.S. Suburbia. City \& Community, 8(3), 221-246.

Hannah-Jones, Nikole (2011). In Portland's Heart, 2010 Census Shows Diversity Dwindling. The Oregonian. Retrieved from www.oregonlive.com/pacific-northwestnews/index.ssf/2011/04/in_portlands_heart_diversity_dwindles.html

Hardwick, Susan, \& James Meacham (2008). Heterolocalism, Networks of Ethnicity, and Refugee Communities in the Pacific Northwest: The Portland Story. The Professional Geographer, 57(4), 539-557.

Harvey, David (1989). The Urban Experience. Baltimore: The Johns Hopkins University Press.

Harvey, David (2007). Limits to Capital. London: Verso.

Hart, Jack (1981a). Annexation Plan Stirs Controversy. The Oregonian, 15 November 1981, E5. 
Hart, Jack (1981b). Quarrel Erupts Over Proposal to Annex Prime Industrial Land. The Oregonian, 15 November 1981, E1.

Hope-Alkon, Alison, \& Julian Agyeman (2011). Cultivating Food Justice: Race, Class, and Sustainability. Cambridge, MA: MIT Press.

Hume, Susan, \& Susan Hardwick (2005). African, Russian, and Ukrainian Refugee Resettlement in Portland, Oregon. Geographical Review, 95(2), 189-209.

Jonas, Andrew, \& Aidan While (2007). Greening the Entrepreneurial City? In R. Krueger and D. Gibbs, editors, The Sustainable Development Paradox: Urban Political Economy in the United States and Europe. New York: The Guilford Press, 123-159.

Katz, Michael, Mathew Creighton, Daniel Amsterdam, \& Merlin Chowkwanyun (2010). Immigration and the New Metropolitan Geography. Journal of Urban Affairs, 32(5), 523-547.

Kneebone, Elizabeth, \& Emily Garr (2010). The Suburbanization of Poverty: Trends in Metropolitan America, 2000 to 2008. The Brookings Institute. Retrieved from www.brookings.edu/ /media/research/files/papers/2010/1/20\%20poverty $\% 20$ kneebone/0120_po verty_paper.pdf

Krishnan, Uma (2012). East Portland Demographics: 2010. City of Portland Bureau of Planning and Sustainability. Retrieved from http://eastportlandactionplan.org/related-documents

Lane, Dee (1990). Major Lenders Aid Decline of NE Portland. The Oregonian. Retrieved from www.kingneighborhood.org/history/Major\%20Lenders\%20Aid\%20Decline\%20of\%20NE\%20Po rtland.pdf

Lansing, Jewel, \& Fred Leeson (2012). Multnomah: The Tumultuous Story of Oregon's Most Populous County. Corvallis, OR: Oregon State University Press.

Law, Steve (2013a). East Side Squeaky Wheel Gets City's Funding Grease. Portland Tribune. Retrieved from http://portlandtribune.com/pt/9-news/135335-east-side-squeaky-wheel-gets-citysfunding-grease

Law, Steve (2013b). 'Next Wave' Swamps East Side. Portland Tribune. Retrieved from http://portlandtribune.com/pt/9-news/158551-next-wave-swamps-east-side

Law, Steve (2013c). Similar Properties, Unequal Taxes. Portland Tribune. Retrieved from http://publications.pmgnews.com/epubs/portland-tribune-011013.pdf

Logan, John, \& Harvey Molotch (2007). Urban Fortunes: The Political Economy of Place. Berkeley: University of California Press. 
Logan, John, Zengwang Xu, \& Brian Stults (2012). Interpolating U.S. Decennial Census Tract Data From as Early as 1970 to 2010: A Longitudinal Tract Database. Professional Geographer.

Longitudinal Tract Database (LTDB) (2013). Spatial Structures in Social Science, Brown University. Retrieved from www.s4.brown.edu/us2010/Researcher/LTDB.htm

Loving, Lisa (2011). Portland Gentrification: The North Williams Avenue that Was - 1956. The Skanner News. Retrieved from http://theskanner.com/article/Portland-Gentrification-The-NorthWilliams-Avenue-That-Was--1956-2011-08-09

Luck-One (2011). Keep Shining. King of the Northwest. [song].

Lycan, Richard (1987). Changing Residence in a Changing City. In L. Price, editor, Portland's Changing Landscape. Portland: Portland State University Department of Geography and the Association of American Geographers.

Marcuse, Peter (1986). Abandonment, Gentrification and Displacement: the Linkages in New York City. In Neil Smith \& Peter Williams, editors, Gentrification of the City. London: Unwin Hyman, 153-177.

McClintock, Nathan (2011). From Industrial Garden to Food Desert: Demarcated Devaluation in the Flatlands of Oakland, California. In Alison Hope Alkon \& Julian Agyeman, editors, Cultivating Food Justice: Race, Class, and Sustainability. Cambridge, MA: MIT Press, 89-120.

Metro (2003). Metro Charter. Retrieved from http://library.oregonmetro.gov/files/charter.pdf

Mirk, Sarah (2010). East of Eden: East Portland is Getting Poorer - and Angrier. Portland Mercury. Retrieved from www.portlandmercury.com/portland/east-ofeden/Content?oid=2462525

Niedt, Christopher (2006). Gentrification and the Grassroots: Popular Support in the Revanchist Suburb. Journal of Urban Affairs, 28(2), 99-120.

Oregon Department of Revenue (n.d.). A Brief History of Oregon Property Taxation. Report Number: 150-303-405-1 (Rev. 6-09). Retrieved from www.oregon.gov/dor/STATS/docs/303405-1.pdf

Parks, Casey (2013). Northeast Martin Luther King Jr. Boulevard Barber Shop Signature Cutz will be demolished for Apartments. The Oregonian.

Retrieved from www.oregonlive.com/portland/index.ssf/2013/10/northeast_martin_luther_king_j.html

Peck, Jamie (2005). Struggling with the Creative Class. International Journal of Urban and Regional Research, 29(4), 740-770. 
Peck, Jamie, \& Adam Tickell (2002). Neoliberalizing Space. Antipode 34(3), 380-404.

Pein, Corey (2011). The Other Portland. Willamette Week. Retrieved from www.wweek.com/portland/article-18071-the_other_portland.html

Portney, Kent (2005). Civic Engagement and Sustainable Cities in the United States. Public Administration Review, 65(5), 579-591.

Preston, Patrick (2012). Eviction Notice: 'I Will Not Leave This House,' Grandmother Vows. KATU News. Retrieved from www.katu.com/news/local/Eviction-Notice-I-will-not-leave-thishouse-grandmother-vows-164094216.html

Provo, John (2009). Risk-Averse Regionalism: The Cautionary Tale of Portland, Oregon, and Affordable Housing. Journal of Planning Education and Research, 28(3), 368-381.

Schafran, Alex (2013). Discourse and Dystopia, American Style: The Rise of 'Slumburbia' in a Time of Crisis. City, 17(2), 130-148.

Schmidt, Brad (2012). Locked Out: The Failure of Portland-Area Fair Housing. The Oregonian. Retrieved from http://projects.oregonlive.com/housing/

Schmidt, Brad (2014). Portland power axis: How the political system, voting behavior limit East Portland's voice. The Oregonian. Retrieved from www.oregonlive.com/portland/index.ssf/2014/07/portland_power_axis_how_the_po.html

Scott, Aaron (2012). By the Grace of God. Portland Monthly. Retrieved from www.portlandmonthlymag.com/issues/archives/articles/african-american-churches-northportland-march-2012/

Slavin, Matt, \& Kent Snyder (2011). Strategic Climate Action Planning in Portland. In M. Slavin, editor, Sustainability in America's Cities: Creating the Green Metropolis. Washington DC: Island Press, 21-40.

Smith, Neil (1982). Gentrification and Uneven Development. Economic Geography, 58(2), 139155.

Smith, Neil (1996). The New Urban Frontier: Gentrification and the Revanchist City. New York: Routledge.

Smith, Neil (2002). New Globalism, New Urbanism: Gentrification as Global Urban Strategy. Antipode.

Smith, Neil (2008 [1984, 1990]). Uneven Development: Nature, Capital, and the Production of Space. Athens, Georgia: University of Georgia Press. 
POST-PRINT VERSION - Goodling, Green, \& McClintock - Urban Geography (2015)

Sullivan, Daniel M., and Samuel C. Shaw (2011). Retail Gentrification and Race: The Case of Alberta Street in Portland, Oregon. Urban Affairs Review 47(3), 413-432.

SustainLane (2008). SustainLane Presents: The U.S. City Rankings. Retrieved from www.sustainlane.com/us-city-rankings/

U.S. Census Bureau (1980a). Census of Housing (1940-1970). Retrieved from www.census.gov/prod/www/decennial.html

U.S. Census Bureau (1980b). Summary Tape File 3 (STF3). Retrieved from www.census.gov/prod/www/decennial.html

American Community Survey (ACS) (2014). 2008-2012, Five-Year Estimate. Retrieved from www.socialexplorer.com

Walker, Richard (1981). A Theory of Suburbanization: Capitalism and the Construction of Urban Space in the United States. In M. Dear \& A. Scott, editors, Urbanization and Urban Planning in Capitalist Society. New York: Methuen.

Webber, Alan (1977). City of Portland Population Strategy. [memorandum].

While, Aidan, Andrew Jonas, \& David Gibbs (2004). The Environment and the Entrepreneurial City: Searching for the Urban 'Sustainability Fix' in Manchester and Leeds. International Journal of Urban and Regional Research, 28(3), 549-569. 